Revista da Rede Brasileira de História da Geografia e Geografia Histórica

$11 \mid 2019$

Mapas e mapeamentos: conhecer, apresentar e agir

\title{
Quando o rio é o caminho
}

O mapa da Comissão Mista de Limites entre o Brasil e o Peru (1874)

When the river is the path: the map by the Mixed Commission of Borders

between Brazil and Peru (1874)

Cuando el río es el camino: el mapa de la Comisión Mixta de Límites entre Brasil y Perú (1874)

Quand la rivière est le chemin: la charte créée par la Commission mixte des

Limites entre le Brésil et le Pérou (1874)

\section{Sabina Alexandre Luz}

\section{(2) OpenEdition}

Journals

Edição electrónica

URL: https://journals.openedition.org/terrabrasilis/4364

DOI: $10.4000 /$ terrabrasilis.4364

ISSN: 2316-7793

Editora

Rede Brasileira de História da Geografia e Geografia Histórica

Refêrencia eletrónica

Sabina Alexandre Luz, "Quando o rio é o caminho», Terra Brasilis [Online], 11 | 2019, posto online no dia 31 agosto 2019, consultado o 05 dezembro 2022. URL: http://journals.openedition.org/terrabrasilis/ 4364 ; DOI: https://doi.org/10.4000/terrabrasilis.4364

Este documento foi criado de forma automática no dia 5 dezembro 2022.

All rights reserved 


\title{
Quando o rio é o caminho
}

\author{
O mapa da Comissão Mista de Limites entre o Brasil e o Peru (1874)
}

When the river is the path: the map by the Mixed Commission of Borders

between Brazil and Peru (1874)

Cuando el río es el camino: el mapa de la Comisión Mixta de Límites entre Brasil

y Perú (1874)

Quand la rivière est le chemin: la charte créée par la Commission mixte des

Limites entre le Brésil et le Pérou (1874)

\section{Sabina Alexandre Luz}

Yo no sé de dónde soy, Mi casa está en la frontera.

Y las fronteras se mueven

Como las banderas.

Jorge Drexler, Frontera

Pensar a relação entre o espaço de fronteira e a nacionalidade é o ponto de partida do presente artigo. Como nos indica Jorge Drexler na epígrafe acima, a fronteira é um espaço onde existe certa fluidez. A definição do limite entre soberanias faz mais sentido para aqueles que buscam traçar detalhadamente o seu território do que para as pessoas que vivem, de fato, nessas áreas de encontro e de circulação.

O principal objeto deste trabalho é um mapa produzido pela Comissão Mista de Limites entre o Brasil e o Peru de 1874. A produção do mapa e o objetivo final dessa comissão se confundem: definir os limites entre os dois países através do rio Javari a partir das suas nascentes. No entanto, no decorrer da exploração desse rio um novo elemento surgiu e definiu o principal tema desse mapa: a presença das populações indígenas do vale do Javari. Resistindo aos avanços advindos da necessidade de demarcação daquela área pelo Estado Imperial, a população nativa atacou as comissões que se aventuravam em seu território.

O comissário brasileiro responsável por essa demarcação era Antônio Luiz von Hoonholtz. Capitão-de-fragata naquele momento, von Hoonholtz havia participado da 
Guerra do Paraguai e ganhara destaque na batalha do Riachuelo. Militar de carreira, escreveu em sua juventude um tratado de hidrografia e tornou-se durante muitos anos o responsável pela Repartição Hidrográfica da Marinha. Além da carreira militar, o futuro barão de Tefé também atuava nas principais associações culturais e científicas do Império, como o Instituto Histórico Geográfico Brasileiro e a Sociedade de Geografia do Rio de Janeiro, da qual foi fundador. Seu prestígio social, portanto, advinha tanto de ser um homem de ação - demarcador de limites nos confins da Amazônia -, como de frequentador dos espaços de ciência situados na capital. ${ }^{1}$

O principal objetivo do presente artigo é propor uma análise do mapa produzido pela Comissão de Limites de 1874. Nesse mapa, questões de territorialidade, alteridade e contruções de narrativas irão aparecer. Tais temas servirão de guia em nossa investigação. $\mathrm{O}$ artigo está dividido em três momentos. Inicialmente, daremos atenção à forma em que ocorreu a locomoção dentro do território amazônico em fins do século XIX, buscando identificar os rios como elementos que marcam essa paisagem e definem o mapa analisado. Em seguida, nos debruçaremos sobre as complexas relações estabelecidas entre a Comissão de 1874 e as populações indígenas do Javari e das regiões adjacentes, assim como sobre as representações e narrativas que surgiram a partir desse encontro, muitas vezes conflituoso. Por fim, faremos algumas indagações sobre a condição desconhecida desse território e a materialidade produzida a partir dele.

\section{Um território fluvial}

Em primeiro lugar, pousemos nosso olhar sobre o mapa da Comissão Mista de Limites entre o Peru e o Brasil (Figura 1), uma redução cinco vezes menor do mapa original do barão de Tefé, feita no Arquivo Militar. 0 mapa analisado neste artigo possui 52 x 66,5 $\mathrm{cm}$, o que nos leva a calcular que sua matriz tinha aproximadamente $2,60 \times 3,32 \mathrm{~m}$, uma dimensão verdadeiramente impactante. ${ }^{2}$ Nesta versão, o primeiro fator que salta aos olhos é provavelmente a disposição dos elementos que compõem o mapa. Encontramos uma legenda grande em sua parte superior direita, onde aparece seu nome (Carta do Alto Rio Javary), as coordenadas geográficas de seus marcos iniciais e finais, a comissão responsável pelo levantamento dessas coordenadas e pela execução do mapa, o ano de execução (1874) e, por fim, o local onde a carta foi reduzida (Arquivo Militar), o autor da redução e o ano respectivo (1875) (Figura 2). 
Figura 1 - Carta do Alto Rio Javary, Bibiano da Fontoura Costallat, 1876

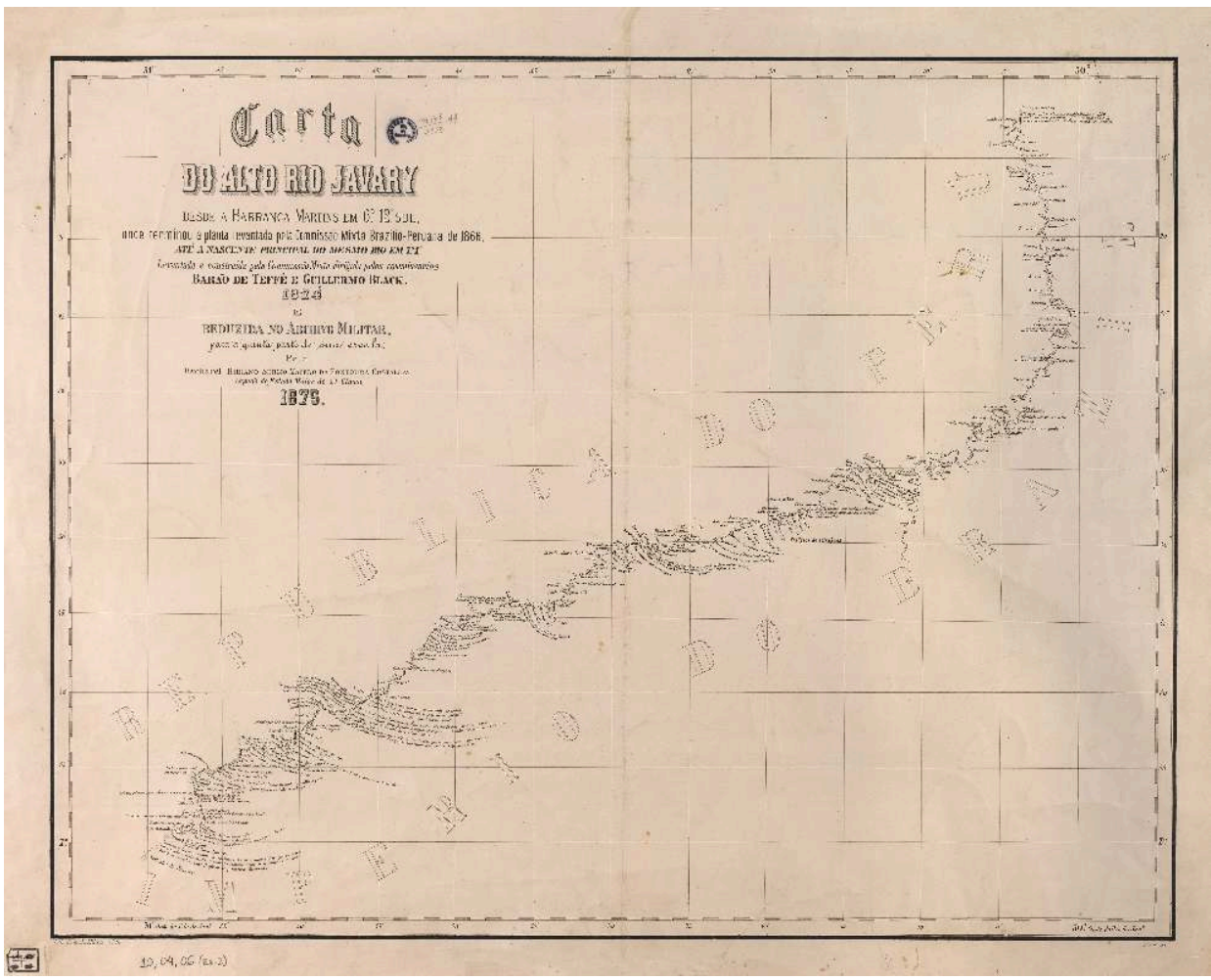

Fonte: Biblioteca Nacional Digital. Biblioteca Nacional do Brasil. http://objdigital.bn.br/objdigital2/ acervo_digital/div_cartografia/cart176173/cart176173.jpg 
Figura 2 - Carta do Alto Rio Javary, Bibiano da Fontoura Costallat, 1876. Detalhe da legenda

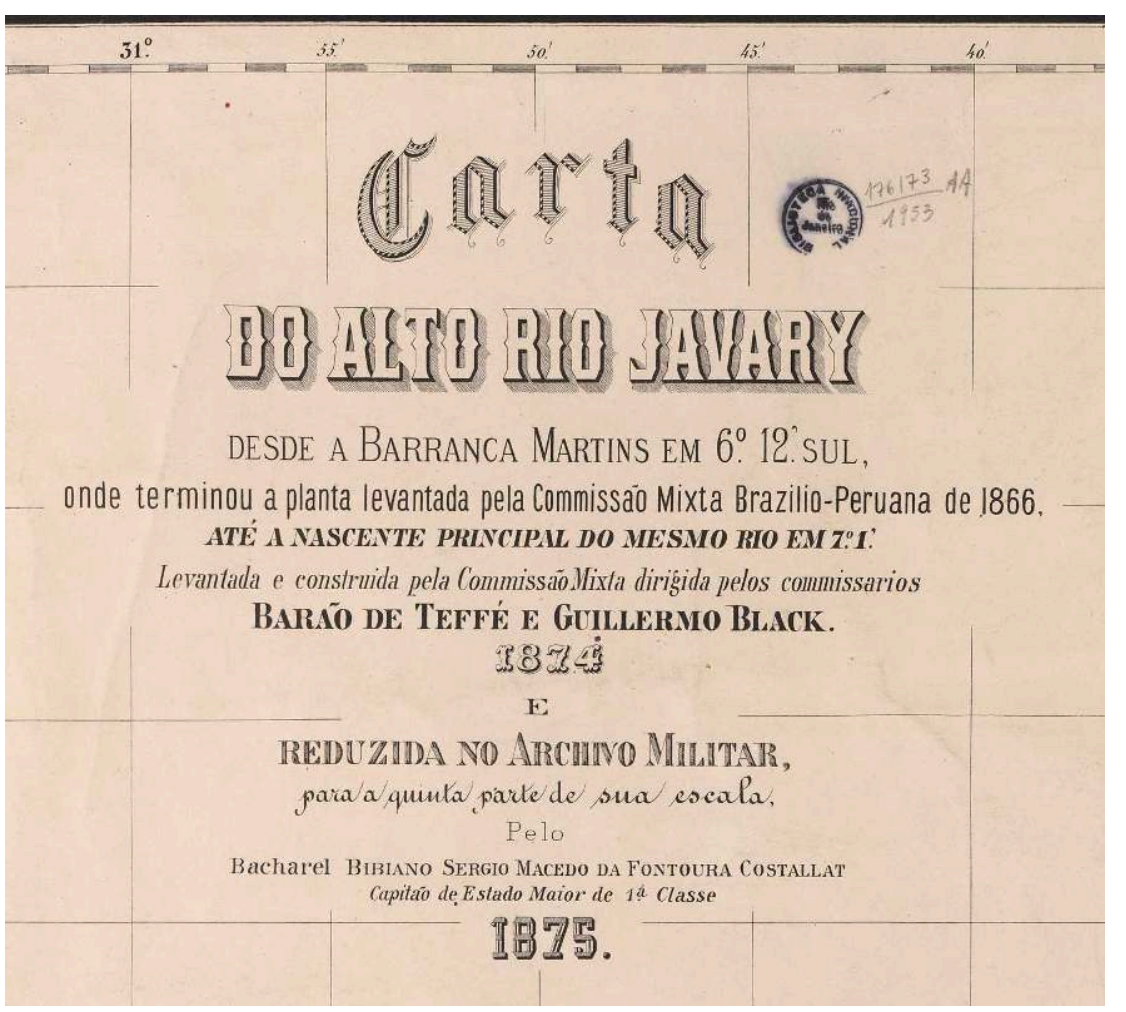

Fonte: Biblioteca Nacional Digital. Biblioteca Nacional do Brasil. http://objdigital.bn.br/objdigital2/ acervo_digital/div_cartografia/cart176173/cart176173.jpg

6 Ao centro do mapa, vê-se uma linha sinuosa acompanhada de pequenos textos e indicações que seguem sua trajetória. Esta linha se projeta da margem superior direita até a margem inferior esquerda. De cada lado dessa linha, há letras enormes, igualmente sinuosas, que, acompanhando as curvas do rio, anunciam: "República do Peru" e "Império do Brazil". Por fim, a carta tem em toda sua margem uma escala que indica os graus de latitude e longitude deste território (compreendendo $29^{\circ} 55^{\prime}$ a $31^{\circ} 5^{\text {, }}$ de latitude Sul e $6^{\circ} 10^{\prime}$ a $7^{\circ} 5^{\prime}$ de longitude Oeste do meridiano do Rio de Janeiro). A partir desta margem surgem linhas que atravessam todo o espaço do mapa, dividindo-o em pequenos quadrados de 5 ' de latitude por 5 'de longitude.

7 A partir desses elementos podemos dizer que o foco do olhar neste mapa fica retido em sua área central, onde a linha sinuosa é apresentada junto com pequenos textos. 0 resto do mapa aparece como um grande vazio. Aqui fica evidente uma característica importante sobre as explorações do território amazônico no século XIX: a forma de penetração se dava sempre por via fluvial. o caminho era determinado pelo leito do rio, ou seja, o caminho era o próprio rio. Cabe lembrar que a Amazônia era coberta por densas florestas de difícil penetração e que a bacia hidrográfica do Amazonas se expandia para o interior do continente. Sendo assim, os rios determinavam não apenas a penetração deste território como também o estabelecimento de aldeias, cidades, entrepostos, zonas comerciais etc. (Corrêa, 1987). Os rios são, portanto, elementos formadores e determinantes desta região.

8 Não podemos esquecer, no entanto, que a exploração da Amazônia ganhou nova dinâmica a partir da segunda metade do século XIX em decorrência da exploração da borracha na região. Assim, o que ficou conhecido como ciclo da borracha (1870-1912) 
foi responsável por uma penetração importante no vale amazônico, que culminou na chamada "questão do Acre": uma disputa pela região do Alto Purus e seus afluentes, que pertencia, então, à Bolívia. ${ }^{3} \mathrm{O}$ interesse econômico da extração da borracha foi liderado majoritariamente por empresas estrangeiras (Machado, 1996). Dessa forma, interesses particulares e estrangeiros dinamizaram a economia regional e ampliaram a exploração da Amazônia, enquanto o governo imperial não a considerava uma região prioritária, ainda que mantivesse relativo controle sobre a área. ${ }^{4} \mathrm{~A}$ situação se alterou no final do século XIX com o advento da República e com a questão do Acre, que trouxe a região Noroeste para o centro de delicados debates políticos, econômicos e diplomáticos.

9 Se disputas territoriais e o argumento da posse pelo uso (uti possidetis) marcaram os debates sobre a região acreana no início do século XX, a fronteira noroeste e sua delimitação já se constituíam vinte e cinco anos antes como objeto de investimento e preocupação por parte do Estado Imperial. De fato, o século XIX representou um avanço importante na demarcação de fronteiras. Segundo Demétrio Magnoli (1997: 242), dos $23.086 \mathrm{~km}$ de extensão do "invólucro fronteiriço do país" (dos quais $15.719 \mathrm{~km}$ são terrestres), $7.948 \mathrm{~km}$ foram estabelecidos durante o Império, enquanto $2.709 \mathrm{~km}$ foram estabelecidos no período colonial e 5.062 km na "era de Rio Branco", já na República.

Considerando esses dados, podemos afirmar que houve um esforço e uma necessidade por parte do Estado Imperial em demarcar suas fronteiras. ${ }^{5}$ Este fato é corroborado pela constatação de alto investimento cartográfico por parte do Estado durante o Segundo Reinado, que culminou, entre outros, na elaboração da Carta Geral do Império de 1875 (Capilé e Vergara, 2012). A produção de mapas e a demarcação de fronteiras são evidentemente dois lados de uma mesma moeda, já que para demarcar o território é preciso conhecê-lo, ou seja, identificar rios, montanhas, calcular coordenadas, estabelecer marcos, etc. De maneira que não pode haver aumento da demarcação de fronteiras sem um aumento considerável da produção de mapas referentes a estas fronteiras.

11 A Carta do Alto Rio Javary (daqui por diante, CARJ) se enquadra precisamente neste caso. Trata-se de um mapa produzido para o estabelecimento da fronteira entre o Brasil e o Peru. As regiões Norte e Noroeste do país não possuíam limites bem definidos no momento da independência (Magnoli, 1987: 182), mas este quadro se alteraria durante o século XIX. No caso da fronteira Brasil-Peru, temos a assinatura da Convenção Especial de Comércio, Navegação Fluvial, Extradição e Limites em 23 de outubro de 1851. No artigo $7^{\circ}$ desta Convenção, aparecia a seguinte proposta de divisão dos territórios:

(...) concordam as altas partes contratantes em que os limites do Império do Brasil com a República do Peru sejam regulados em conformidade do princípio de uti possidetis; por conseguinte reconhecem, respectivamente, como fronteira a povoação de Tabatinga; e daí para o Norte em linha reta a encontrar o rio Japurá, defronte da foz do Apoporis; e de Tabatinga para o Sul, o rio Javari, desde a sua confluência com o Amazonas. Uma comissão mista nomeada por ambos os governos reconhecerá, conforme ao princípio uti possidetis, a fronteira, e proporá a troca dos territórios que julgar a propósito para fixar os limites que sejam mais naturais $e$ convenientes a uma e outra nação. (Brasil. Convenção Especial..., 1851, grifos nossos) ${ }^{6}$

12 Neste artigo aparecem três elementos importantes sobre a fronteira: em primeiro lugar o estabelecimento da doutrina jurídica do uti possidetis, ou seja, da legitimação dos territórios fronteiriços pela posse efetiva dos mesmos; em seguida aparecem os pontos de limite entre as nações a partir de cidade e rios conhecidos (Tabatinga, rio Japurá, rio 
Javari); e, finalmente, o texto menciona a necessidade de criação de uma comissão mista para reconhecer e fixar os limites mencionados no tratado e propor eventuais alterações.

Para os objetivos desta investigação, interessa-nos especialmente a demarcação mencionada nesse tratado na fronteira Sul de Tabatinga, onde a referência geográfica utilizada era o rio Javari. Este último era tido como uma fronteira natural desde a época colonial, já que os portugueses conseguiram afirmar a sua presença a partir da fundação de Tabatinga. Assim, se a fronteira amazônica era bastante fluida quanto ao estabelecimento dos limites entre os impérios espanhol e português, os rios Madeira e Javari apareciam como uma exceção dentro deste quadro (Peixoto, 2002). No entanto, cabe lembrar que apesar da referência a esse rio ser histórica, o conhecimento de seu leito assim como as coordenadas de suas nascentes ainda não haviam sido objeto de confirmação oficial até aquele momento. Compreende-se, portanto, o papel e importância das comissões mistas que, uma vez sobre o terreno, puderam estabelecer e ajustar os limites entre os territórios dos dois países.

A Comissão Mista de Demarcação de Limites entre o Brasil e o Peru foi organizada desde 1861. No entanto, as conferências preliminares aos trabalhos de demarcação só ocorreram a partir de 1865 e os trabalhos de campo se deram no ano de 1866 (Brasil. O Tratado de Limites..., 2009: 82). Os representantes do Brasil e do Peru na comissão eram, respectivamente, o capitão-tenente José da Costa Azevedo (posteriormente barão de Ladário) e o capitão-de-Mar e Guerra Francisco Carrasco (Brasil. Relatório da Repartição dos Negócios Estrangeiros, 1867: 14). Diversos trabalhos de reconhecimento e demarcação foram realizados por essa comissão. Os trabalhos relativos ao rio Javari foram chefiados pelo capitão-tenente João Soares Pinto e o geógrafo Manoel Rouaud y Paz Soldan, ambos membros da comissão. Os trabalhos de demarcação do rio Javari foram interrompidos em 1866 devido aos ataques dos indígenas do vale do Javari, que provocaram a morte de Soares Pinto e deixaram Paz Soldan gravemente ferido.

Uma nova comissão de demarcação de limites formou-se em 1871, tendo, desta vez, como representante brasileiro o capitão-de-fragata Antônio Luiz von Hoonholtz (posteriormente barão de Tefé) e do lado peruano o mesmo Paz Soldan (Brasil. Relatório..., 1871: 28). ${ }^{7}$ Esse último faleceu e foi substituído, em 1872, pelo capitão-defragata Dom Guilherme Black (Brasil. Relatório..., 1871: 4). Entre janeiro e maio de 1874, sob o comando do barão de Tefé e de Guilherme Black foram feitos os levantamentos e demarcações que constam na CARJ.

Como o título indica, esse mapa é uma carta náutica ou carta hidrográfica que tem como objetivo principal apresentar as condições de navegabilidade de um rio e suas principais características. Assim, temos na CARJ constantes indicações sobre o rio Javari. São sinalizadas a profundidade do rio, a velocidade da correnteza, as barreiras existentes em suas margens e sua vegetação, a largura do rio, a presença de areia, argila e cascalho, a existência de ilhas, os afluentes do Javari e o nome que recebem (Figura 3). 
Figura 3 - Carta do Alto Rio Javary, Bibiano da Fontoura Costallat, 1876

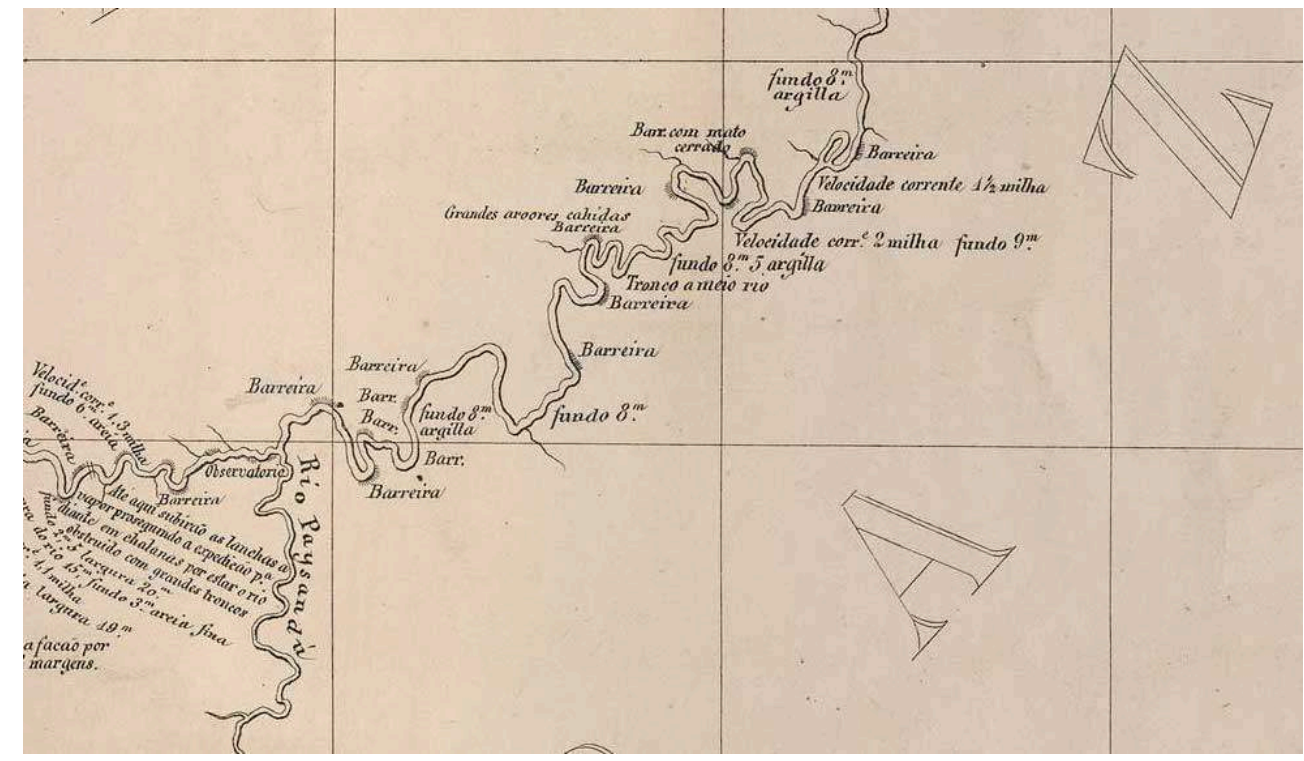

Detalhe dos elementos de navegabilidade indicados no mapa: fundo, velocidade da correnteza, barreiras etc. Notar a indicação "observatório": a comissão precisava fazer constantes observações astronômicas para medir alturas de estrelas, encontrar o meridiano local e calcular as coordenadas.

Fonte: Biblioteca Nacional Digital. Biblioteca Nacional do Brasil. http://objdigital.bn.br/objdigital2/ acervo_digital/div_cartografia/cart176173/cart176173.jpg

Entretanto, o mapa analisado no presente artigo possui características que o distinguem de outras cartas náuticas do período, já que incorpora a essas informações de navegabilidade, uma narrativa (bastante dramática) sobre as dificuldades da viagem decorrentes, sobretudo, da presença indígena na região. 0 mapa possui, desta maneira, uma importante parte textual que consiste em indicações e comentários escritos ao longo do leito do rio, em ambas as margens. Antes de analisarmos o conteúdo dessas anotações, vejamos rapidamente alguns exemplos de mapas do mesmo período e da mesma região (figuras 4 a 7 ) para compreendermos a especificidade do mapa apresentado e algumas características dessa região. 
Figura 4 - Carta Hydrographica do Rio Javary, João Soares Pinto, 1866. Folha 1

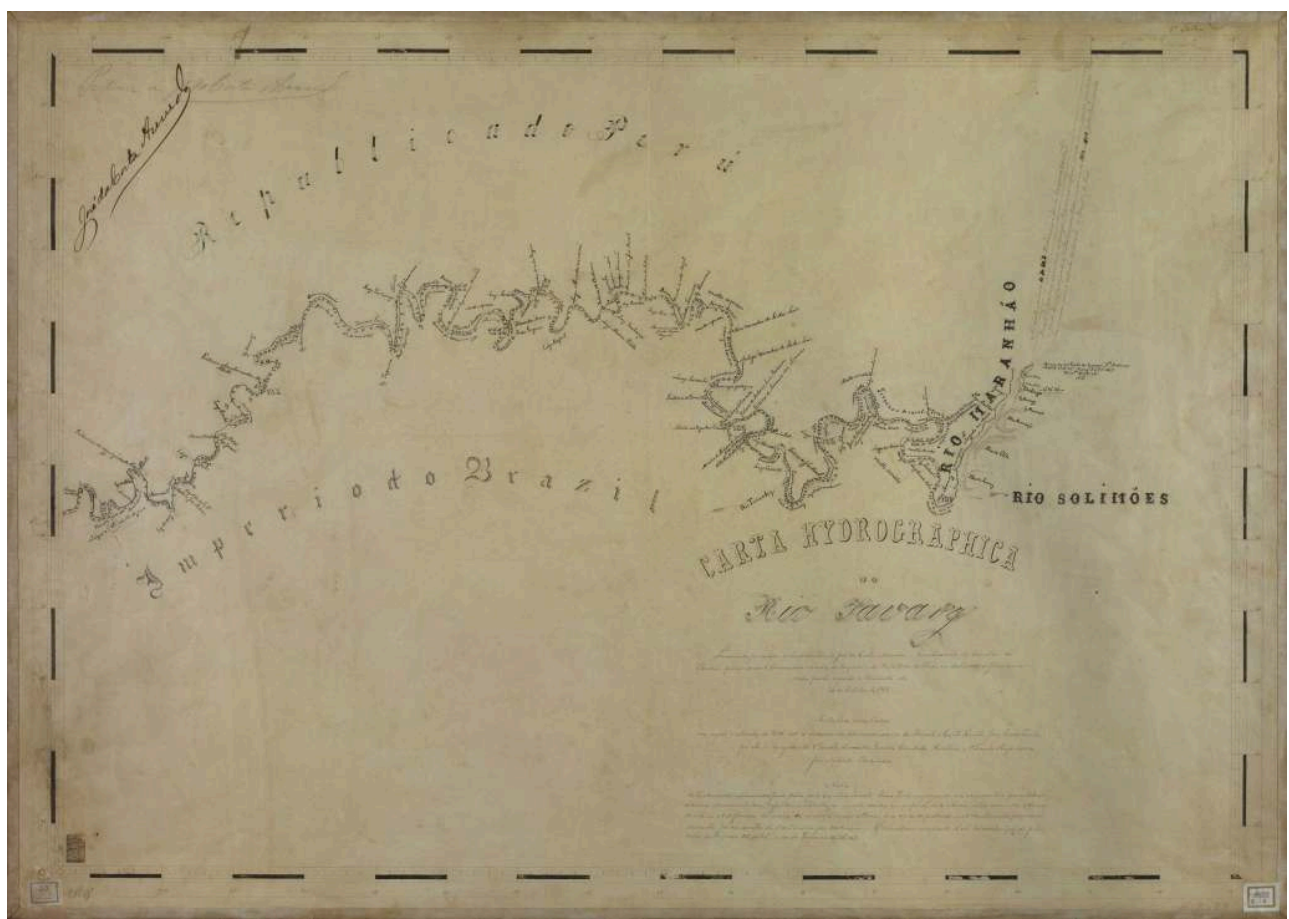

Fonte: SIAN - Sistema de Informações do Arquivo Nacional. Arquivo Nacional do Brasil. http:// sian.an.gov.br/sianex/Consulta/Pesquisa_Livre_Painel_Resultado.asp? v_CodReferencia_id=95656\& $\_$aba $=1$

Figura 5 - Carta Hydrographica do Rio Javary, João Soares Pinto, 1866. Folha 2

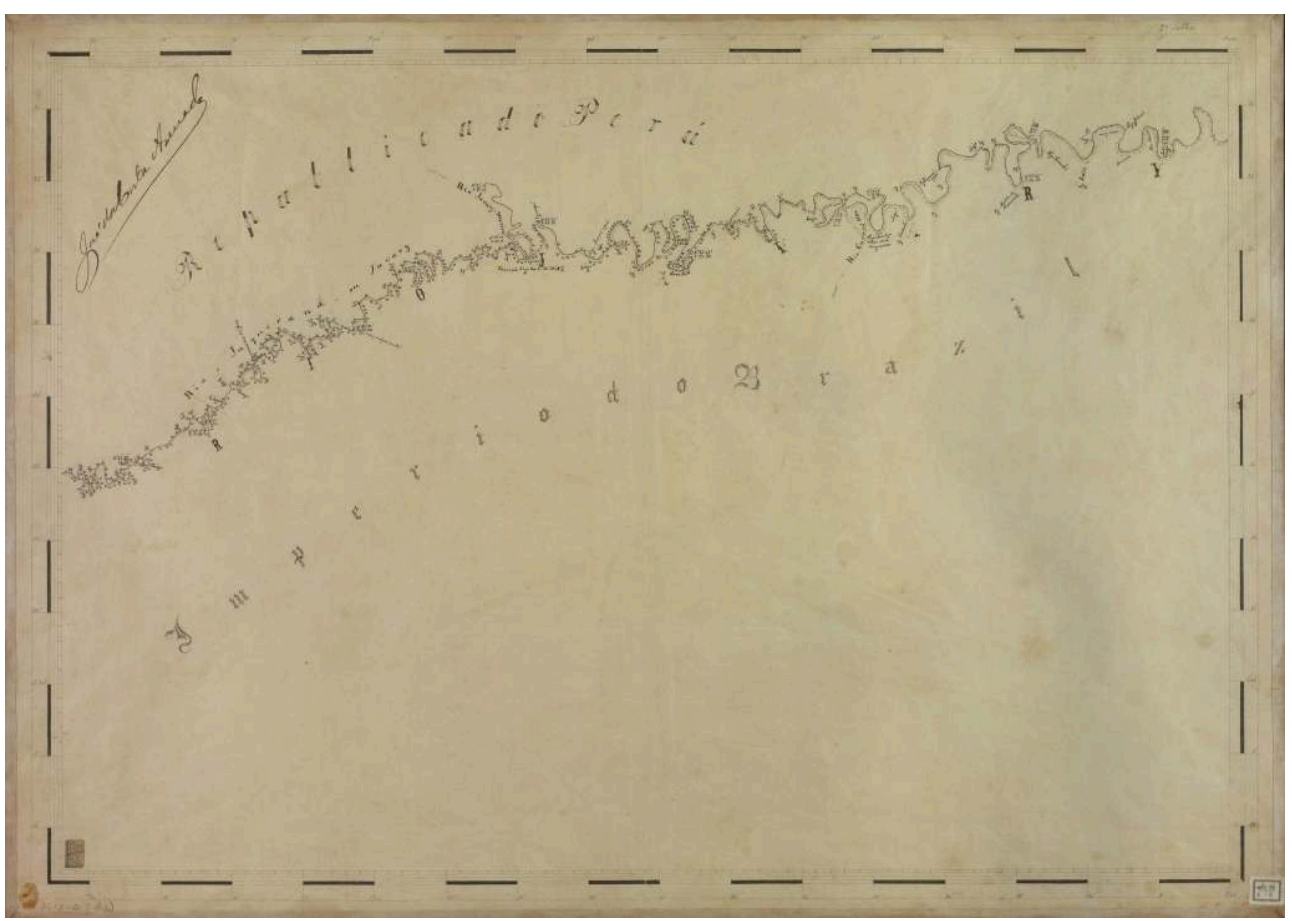

Fonte: SIAN - Sistema de Informações do Arquivo Nacional. Arquivo Nacional do Brasil. http:// sian.an.gov.br/sianex/Consulta/Pesquisa_Livre_Painel_Resultado.asp?

v_CodReferencia_id $=95656 \&$ v_aba=1 
Figura 6 - Carta Hydrographica do Rio Javary, João Soares Pinto, 1866. Folha 3

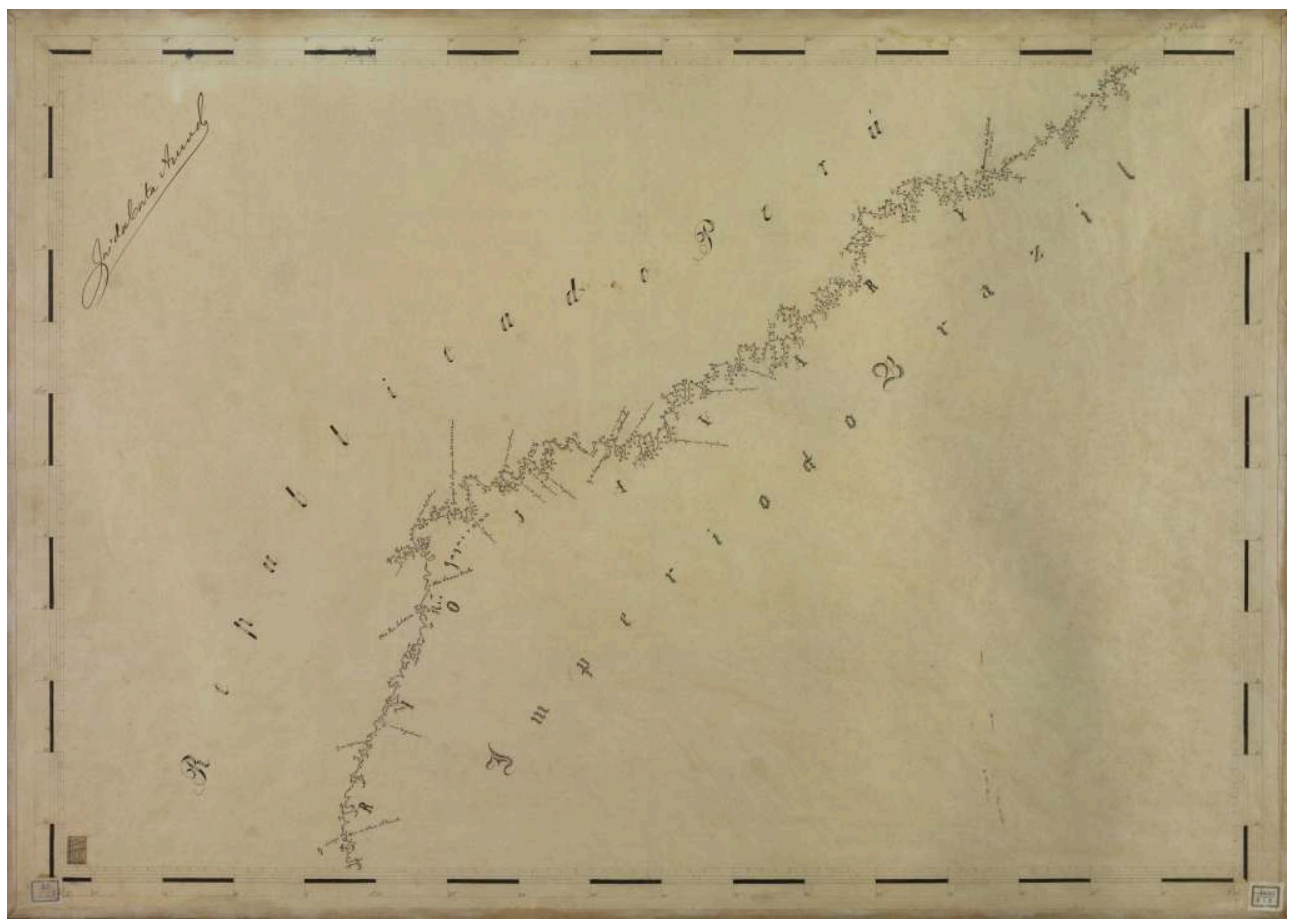

Fonte: SIAN - Sistema de Informações do Arquivo Nacional. Arquivo Nacional do Brasil. http:// sian.an.gov.br/sianex/Consulta/Pesquisa_Livre_Painel_Resultado.asp?

v_CodReferencia_id=95656\&v_aba=1

Figura 7 - Carta Hydrographica do Rio Javary, João Soares Pinto, 1866. Folha 4

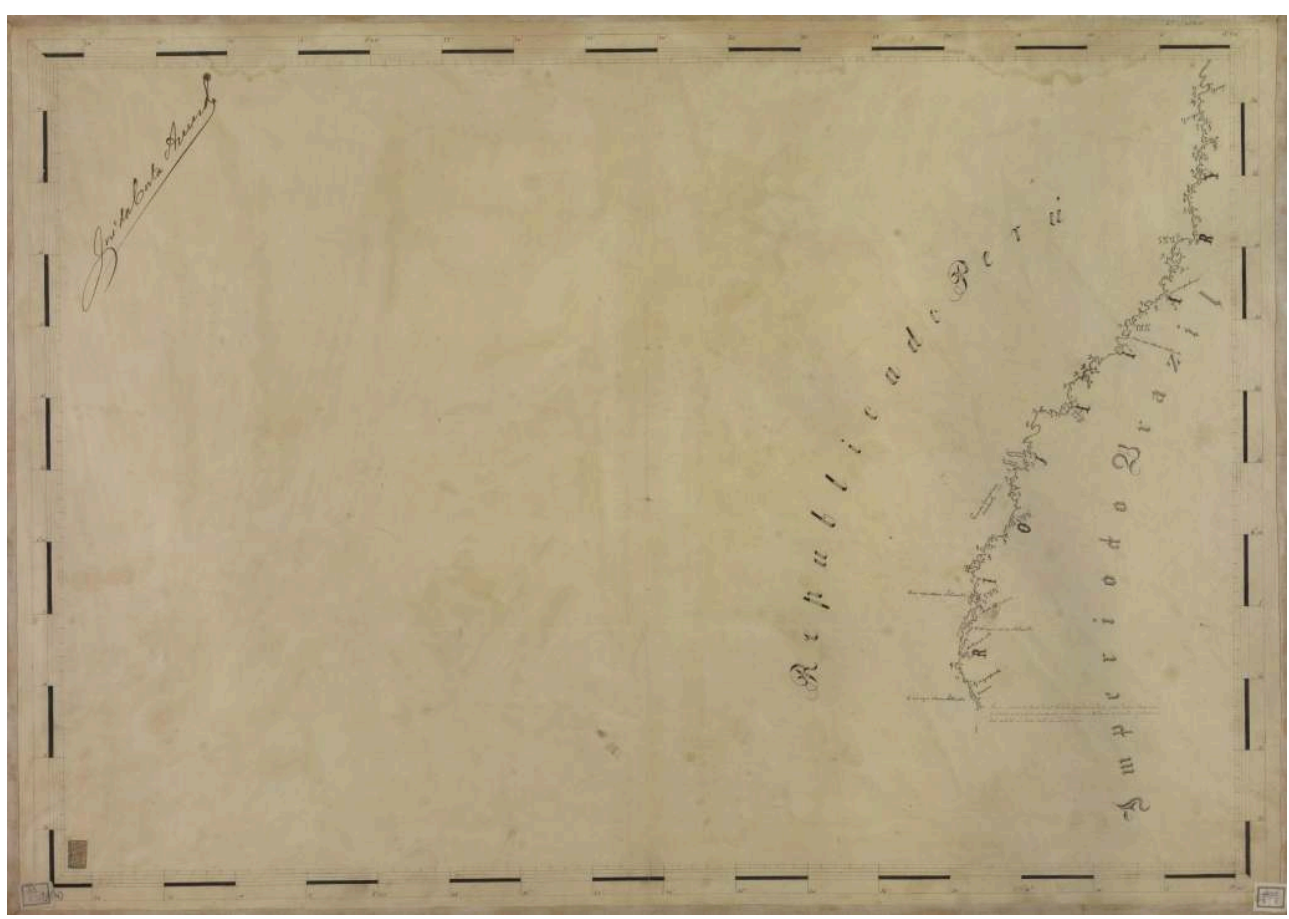

Fonte: SIAN - Sistema de Informações do Arquivo Nacional. Arquivo Nacional do Brasil. http:// sian.an.gov.br/sianex/Consulta/Pesquisa_Livre_Painel_Resultado.asp?

v_CodReferencia_id=95656\&v_aba=1 
Em primeiro lugar temos a Carta Hydrographica do Rio Javary, de 1866, elaborada pelo capitão-tenente João Soares Pinto com o auxílio de Geraldo Candido Martins e José Antônio Rodrigues, todos membros da Comissão Mista de Limites entre o Brasil e o Peru de 1866. A carta, de pequenas dimensões $(57$ x $82,5 \mathrm{~cm})$, possui 4 folhas. Dessa maneira, o curso do rio do ponto inicial em Tabatinga até o ponto final na latitude Sul 6¹2' não pode ser visto de maneira contínua, à diferença da CARJ. Uma semelhança entre as duas cartas é a escala da margem que indica os graus de latitude e longitude deste território, divididos a cada 5'. Como outras cartas hidrográficas, a Carta Hydrographica do Rio Javary também indica a profundidade do rio, a presença de igarapés, lagos, ilhas, descrição da vegetação das margens, além de dar algumas indicações sobre moradias ao longo do rio, que algumas vezes são indígenas. Interessante notar que a partir da folha 2 já não são mencionadas moradias às margens do Javari. ${ }^{8} \mathrm{~A}$ presença indígena foi indicada no final, com a seguinte anotação:

Com a morte do Snr. Capitão-Tenente João Soares Pinto, pelos Índios deste rio, perderam-se os papéis que davam mais cerca de 80 léguas de planta: faleceu ao Sul de $6^{\circ} 50^{\prime}$ e a Oeste de $4^{\circ}$ de Tabatinga. (Carta Hydrographica do Rio Javary, 1866)

Percebemos que as referências à população indígena do vale do Javari são bastante pontuais e nenhum comentário sobre as circunstâncias da viagem ou do ataque indígena foi feito no próprio mapa. Essas informações aparecem, no entanto, em ofícios publicados no Relatório da Repartição dos Negócios Estrangeiros, que veremos a seguir. Por enquanto, gostaríamos apenas de evidenciar de que maneira a CARJ destoa de outras cartas náuticas do mesmo período. Podemos dar outros exemplos de cartas náuticas que possuem estrutura semelhante à Carta Hydrographica do Rio Javary e não apresentam elementos textuais muito longos. Um desses mapas, a Carta do Rio Javary, publicada em 1868, é a versão impressa da Carta Hydrographica do Rio Javary. Percebese que para a impressão, algumas indicações foram suprimidas, deixando o mapa um pouco menos carregado de informações. Outro exemplo é a Carta do rio Içá, levantada pelo mesmo José da Costa Azevedo, também durante os trabalhos da Comissão Mista de Demarcação de Limites Brasil-Peru, que mantém a mesma estrutura da precedente.

Cabe observar, por fim, que tanto a Carta Hydrographica do Rio Javary quanto a Carta do Rio Javary sinalizam o pertencimento dos territórios existentes em cada uma das margens do rio com as inscrições "República do Peru" e "Império do Brasil". Estas indicações são sempre feitas com letras bastante grandes e destacadas. Assim, fica evidente o objetivo principal desses levantamentos: o estabelecimento dos limites entre os dois países. As implicações políticas e estratégicas relacionadas à confecção desses mapas também fica evidente. Afinal, de todas as informações, essas são as que se destacam. No entanto, para cumprir esse objetivo de demarcação dos limites era preciso lidar não apenas com a dificuldade de acesso do local, mas sobretudo com a população indígena do Javari que resistia às investidas das comissões de demarcação. Razão pela qual tornaram-se um dos principais elementos presentes na CARJ.

\section{Um território habitado}

21 A CARJ apresenta, após a indicação do encontro com o rio "Paysandu", um novo elemento em suas informações e comentários: a presença indígena e suas manifestações. Essa última passa a ser sinalizada a partir de uma área destacada no mapa com a inscrição "vestígios de selvagens". Esta indicação foi posta um pouco mais 
afastada do curso do rio e o tamanho de suas letras é maior. Assim, podemos interpretar a mensagem como uma espécie de alerta e perceber a relação entre esses "selvagens" e a espacialidade do mapa. o lugar escolhido para indicar esta presença pode apontar a relação entre seus habitantes e este grande espaço "vazio" que marca a CARJ: se o acesso a estas terras era difícil, sabia-se que ali existiam povos indígenas que habitavam e dominavam aquele espaço. Se o rio era o único acesso seguro para o Estado e seus agentes, as terras ao seu redor eram dominadas por povos indígenas chamados de "selvagens" na CARJ, por serem vistos como elemento de resistência à civilização (representada pelos agentes do Estado). Resistência essa que tomava diversas formas, dentre as quais, ataques às expedições que se aventuravam nestas regiões.

A próxima referência que podemos encontrar na CARJ menciona justamente um desses ataques. Alguns quilômetros depois (avançando em direção à nascente do rio) da indicação "vestígio de selvagens", a aproximadamente $6^{\circ} 40^{\prime}$ Sul e $30^{\circ} 27^{\prime}$ Oeste, aparece o texto a seguir: "neste lugar foi desbaratada pelos selvagens a expedição demarcadora de 1866, sendo morto o Chefe Brasileiro Soares Pinto e feridos os demais exploradores. o Chefe Peruano Paz Soldan teve de amputar a perna.". A comissão mista demarcadora de limites entre o Brasil e o Peru de 1866, como vimos, constituiu a primeira tentativa de exploração do rio Javari até suas nascentes com o intuito de demarcar o limite estabelecido pela Convenção de 1851. Como mencionado na CARJ, a comissão explorava o rio quando sofreu um duro ataque indígena naquela região, tendo como consequência um grande número de feridos e algumas mortes, dentre as quais a do próprio chefe da expedição brasileira.

O episódio deste ataque foi relatado pelo tenente José Antônio Rodrigues ao tenente Geraldo Candido Martins, que esperava o retorno da comissão de 1866 no ponto onde começa a CARJ de $1874 .{ }^{9}$ José Rodrigues explica neste ofício que a comissão ficou com pouca munição devido a um acidente com uma das canoas, provocando a queda na água da caixa que continha as espoletas, fato que prejudicou a reação da expedição no dia 10 de outubro de 1866. Neste dia, houve um primeiro ataque indígena às oito e meia da manhã: "no momento em que chegávamos a um lugar onde o rio estava obstruído por paus, três flechas, saídas do mato, caíram sobre uma das nossas canoas, a menor, deixando um homem ferido". Após este episódio Soares Pinto decide regressar "por estar falto de meios de defesa" (Relatório..., 1867: 106). No entanto, a comissão é surpreendida no retorno por um novo ataque, desta vez, bem maior:

Eram os índios que de novo acometiam, mas desta vez frente a frente, a peito descoberto e saltando o seu grito de guerra. Tentamos responder ao desafio, mas tivemos um rude desengano. (...) Os selvagens flechavam-nos sossegadamente; e nem uma só bala nossa os ia repelir por causa das espoletas que, humedecidas e desvirtuadas, negavam fogo com uma constância desesperadora. (Relatório..., 1867: 106)

24 As consequências destes ataques foram, portanto, fatais não apenas no que se refere ao número de homens mortos e feridos, mas também à própria expedição que, a partir desse ponto, perdeu o comissário brasileiro, ficando portanto sem condições de prosseguir em seus trabalhos.

É interessante perceber a partir destas informações de que maneira a CARJ recupera a memória da primeira experiência malsucedida e, ao especificar os pontos onde os primeiros ataques ocorreram, este documento estabelece uma continuidade entre os dois momentos. Seu ponto de partida já indica esta sucessão visto que a "Barreira Martins" é o ponto onde o tenente Geraldo Martins da comissão de 1866 aguardava o 
retorno da mesma. E, como se lê no próprio documento, “onde termina o mapa desta infeliz expedição e da qual partiu a comissão mista de 1874 em procura das vertentes".

Cabe salientar que esta continuidade não é sem propósito. Ao contrário, a comissão mista de 1874, que iniciou seus trabalhos em 1871, foi criada justamente para "dar prosseguimento aos trabalhos interrompidos em 1867" (Brasil. Ministério das Relações Exteriores..., s/d: 3). De fato, a exploração do rio Javari era necessária para o estabelecimento e demarcação da fronteira e dos limites entre Brasil e Peru. Apesar dos avanços feitos em 1866, era preciso chegar à nascente deste rio para que a fronteira pudesse ser de fato demarcada. Assim, a continuidade entre as duas comissões era evidente. No entanto, o fato do mapa de 1874 resgatar os episódios violentos que marcaram a comissão de 1866 e determinar o local onde esses encontros se deram mostra mais do que a simples continuidade entre as duas comissões.

Podemos, por um lado, pensar no esforço da comissão de 1874 de dar materialidade à empreitada final de 1866, já que, como nos informa mais uma vez José Rodrigues: “Dos cadernos de notas da comissão nem um se salvou: as alagações repetidas da canoa a noite deram cabo de todos eles" (Brasil. Relatório..., 1867: 107). Assim, os trabalhos executados pela comissão de 1866 até a Barreira Martins puderam ser salvos por terem permanecido neste local, como afirma o tenente Geraldo Martins: ${ }^{10}$

Nos dois volumes, que restam dos trabalhos feitos, encontrará V. S. minuciosamente a descrição do que executara a comissão até o dia 21 de setembro à tarde em que o Sr. Soares Pinto resolveu dividir a expedição, no intuito de melhor prosseguirem os trabalhos. (Brasil. Relatório..., 1867: 108)

Percebemos então que a partir da Barreira Martins, a trajetória da comissão de 1866 havia sido interrompida devido às difíceis circunstâncias do retorno que provocaram a perda total dos documentos elaborados. ${ }^{11}$ Ainda que os relatos sobre estes episódios existissem (como vimos nos ofícios citados), a incorporação no mapa de 1874 do ponto onde $\mathrm{o}$ ataque aconteceu e a lembrança de suas trágicas consequências para os membros da comissão mostram a preocupação em não apenas resgatar como se apropriar e redefinir funções sobre os eventos ocorridos oito anos antes. Desta maneira, consideramos que a presença deste episódio na CARJ ajuda a reforçar a imagem agressiva e perigosa vinculada às populações indígenas que habitavam as margens do alto curso do rio Javari. Interpretação esta que vai ser reafirmada na narrativa da CARJ para os episódios de encontro com estas populações nativas em 1874 .

Depois do ponto onde está assinalado o ataque indígena da comissão mista de 1866, aparece uma indicação, na margem direita do rio: “estrada limpa dos índios”. Mais uma vez, percebe-se que a presença indígena (e sua ausência, como não presença) se constitui como um elemento que recebe contínua atenção dos expedicionários e que, por isso mesmo, é expressamente indicada no mapa. Dois elementos surgem a partir desta constatação. Por um lado, fica evidente a sobreposição do mapeamento do território ao mapeamento das populações indígenas. Característica que vem de uma tradição na produção de corografias, ou seja, do entendimento de conhecer o território através de seus "elementos naturais e humanos presentes nesse espaço" (Kodama, 2009: 37). Assim, geografia e etnografia aparecem atreladas durante o século XIX no Brasil. ${ }^{12}$ Por outro lado, a preocupação com os espaços ocupados pelos índios do Javari também revela a percepção deste grupo como um perigo, uma constante ameaça. Evidentemente a experiência precedente de 1866 e o fracasso da expedição contribuem para esta postura. No entanto, cabe lembrar que havia uma categorização dos índios 
durante todo o século XIX: de um lado, a figura dos "índios bravos" e, contrapondo-se a ela, os índios "domésticos ou mansos" (Cunha, 1998: 136). Assim, os índios do Javari são colocados e tratados nessa primeira categoria. ${ }^{13}$

O encontro com essas populações era inevitável e não tardou a ocorrer. A presença cada vez maior de inúmeros troncos de árvores que serviam de pontes e boqueavam a passagem das chalanas da comissão Tefé-Black indicavam a circulação destes povos autóctones naquela área e, portanto, sinalizavam que a comissão já estava em seu território. Um primeiro encontro ocorreu um pouco depois do ponto $6^{\circ} 50^{\prime}$ Sul e $30^{\circ} 45^{\prime}$ Oeste, que mereceu o seguinte registro no mapa: "[neste local] houve um tronco por onde os Índios atravessavam, e nos atacaram, mas foram completamente derrotados e morto um com uma bala no crânio".

Figura 8 - Carta do Alto Rio Javary, Bibiano da Fontoura Costallat, 1876

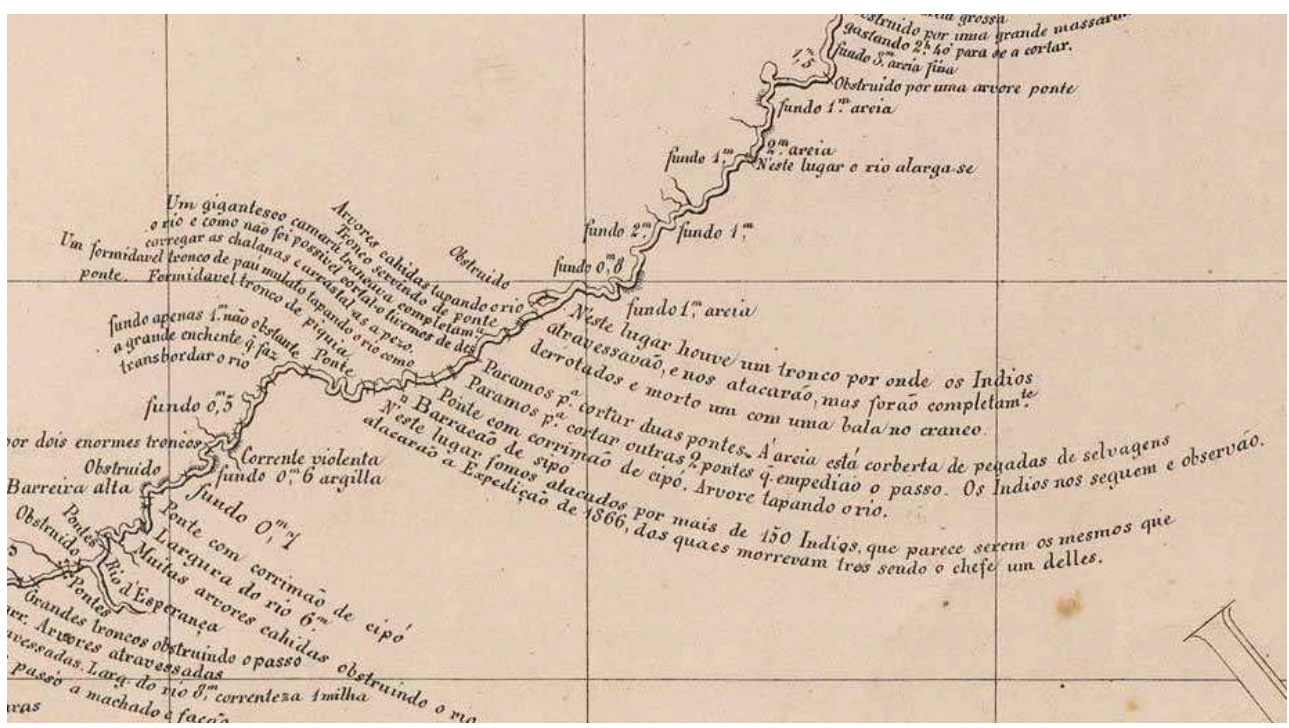

Note-se as numerosas linhas horizontais no curso do rio indicando a presença de árvores usadas como pontes.

Fonte: Biblioteca Nacional Digital. Biblioteca Nacional do Brasil. http://objdigital.bn.br/objdigital2/ acervo_digital/div_cartografia/cart176173/cart176173.jpg

31 A partir deste ponto as pontes e obstruções do caminho tornaram-se extremamente recorrentes ${ }^{14}$ (figura 8), assim como a presença e observação das populações indígenas. Algumas anotações revelam a proximidade com que esses habitantes acompanhavam a comissão: "A areia está coberta de pegadas de selvagens"; "os índios nos seguem e observam". Acompanhando o avanço da comissão, eles decidem agir e fazem um novo ataque, registrado no mapa: "Neste lugar fomos atacados por mais de 150 Índios, que parece serem [sic] os mesmos que atacaram a Expedição de 1866, dos quais morreram três sendo o chefe um deles". Os episódios de ataque e enfrentamento com estas populações são assinalados de maneira bastante sucinta e fica evidente a valorização do uso das armas que permite aos membros da comissão derrotá-los "completamente". Nos dois ataques indicados temos, no total, quatro mortes do lado dos indígenas e nenhuma morte é apontada do lado dos expedicionários. ${ }^{15} \mathrm{O}$ uso das armas de fogo aparece, desta maneira, como o elemento-chave do processo de conquista destes territórios. 
Se as circunstâncias e o encadeamento dos episódios de ataques indígenas não foram longamente descritos no mapa, uma parte dos relatos da expedição do barão de Tefé foi publicada posteriormente na Revista da Sociedade de Geografia do Rio de Janeiro (Tefé, 1888). Esta publicação nos ajuda a complementar os curtos relatos descritos no mapa e a perceber um quadro de relações entre os membros da comissão de 1874 e as populações indígenas mais complexo do que a leitura do mapa nos faria crer. Temos, assim, uma descrição sobre os dois episódios de enfrentamento que ocorreram até este ponto. 0 primeiro deles é descrito da seguinte maneira:

Quando tomava a segunda série de alturas fui interrompido pelo estampido de um tiro, seguido de vários outros. (...) Referiu-me o que rompera o fogo, ter percebido um ligeiro movimento na folhagem de umas plantas rasteiras que lhe ficavam a poucos passos de distância, e que supondo ser uma cobra, dessas terríveis jararacussus que tanto abundam aqui, engatilhara a arma, quando, com o tic-tac do gatilho, vira de repente saltar da moita um selvagem e uma flecha sibilar junto ao ouvido. Fez fogo então e o índio caíra, ao mesmo tempo que de todos os lados surgiram da terra outros muitos que dispararam desordenadamente seus arcos e lançando-se de novo ao chão desapareceram quase de rastos, sem que os tiros dos companheiros servissem mais do que para afugentá-los. (Tefé, 1888: 176, grifos do autor)

Alguns elementos novos aparecem nessa narrativa. As circunstâncias do ataque tornam-se mais claras e percebemos que o clima de desconfiança reinava em ambas as partes envolvidas. Por um lado, os membros da comissão mista de 1874 tinham diante de si uma grande variedade de adversidades: a possibilidade de um ataque indígena estava sempre presente, mas os perigos da selva com sua fauna rica e ameaçadora estava na ordem do dia. Por outro lado, fica claro nesta passagem que o encontro entre a população nativa deste território e o os membros destas comissões era permeado por relações de desconfiança mútua onde os conceitos de ataque e defesa não são absolutos. Ao que o barão de Tefé chama de ataque, neste caso, poderia ser entendido como defesa dos indígenas que viam seu território ser invadido (mais de uma vez) por homens armados. 0 episódio relatado mostra igualmente que estas populações acompanhavam de perto as ações dos expedicionários, mas não fica claro se a intenção desse grupo era de fato efetuar um ataque surpresa ou se eles foram surpreendidos com a proximidade desse homem e, apenas nesse momento, o atacaram.

As relações entre as populações indígenas e os membros da Comissão Demarcadora de limites entre o Brasil e o Peru não era somente de enfrentamento. Em outra passagem do mesmo texto, barão de Tefé menciona alguns grupos indígenas que colaboravam e faziam parte dessa expedição:

Desejoso de saber se a tribo senhora desta região é a mesma dos Mangeronas, que, a umas 50 milhas abaixo do lugar em que estamos destroçou em 1866 a comissão mista presidida por Soares Pinto e Paz Soldan, eu fiz examinar o corpo [do indígena morto] pelos Índios Ticunas que eu trouxe comigo como remadores e intérpretes, assim também pelos Jeveros, que guarnecem as chalanas peruanas; mas nem pela pintura, nem pelas armas puderam eles reconhecer a nação. Estamos portanto em território dominado por tribo completamente desconhecida. (Tefé, 1888: 177, grifos do autor)

Algumas informações importantes aparecem nesse trecho. Primeiramente, quanto à identificação do grupo indígena que habitava as margens do Javari e atacou a expedição de 1866, os "Mangeronas". Tefé supôs, em 1874, que os índios que o atacaram não eram deste grupo (já que eles não foram reconhecidos pelos Ticunas, nem pelos Jeveros), tratando-se, portanto, de "tribo completamente desconhecida". Mangerona pode ser 
uma alteração de Mayoruna, etnônimo frequentemente utilizado para os povos do Javari em diversas fontes e que continua sendo utilizado sobretudo na parte brasileira da fronteira com o Peru (Coutinho, 2017: 25). ${ }^{16}$ Ainda assim, cabe sinalizar que essas denominações, muitas vezes impostas, não são absolutas e que frequentemente se referem a mais de um grupo, como é o caso dos Mayorunas. ${ }^{17}$

Destacando a diversidade dos povos do vale do Javari, cabe salientar que, ainda hoje, essa é "uma área contínua de alta floresta que abriga o maior número de índios isolados da América Latina e, provavelmente, do mundo" (Arisi e Milanez, 2017: 51). De fato, a área de fronteira entre o Brasil e o Peru, que engloba o alto curso do rio Javari, se constitui como uma extensa área de circulação de populações que estão, até hoje, "isoladas". Como esclarecem Arisi e Milanez, este isolamento não é, necessariamente, completo e não significa a ausência de qualquer contato com os brancos. Ele pode ser um isolamento voluntário, como uma forma de se proteger, inclusive (Nascimento, 2011).

Em segundo lugar, como fica evidente no trecho citado, os "Ticunas" e os "Jeveros" não apenas auxiliavam como participavam de forma direta das atividades da comissão de limites. Assim, temos aqui uma quebra na estrutura rígida apresentada na CARJ, onde os povos nativos assumem somente um papel de inimigos do Estado e, enquanto tais, constituem um perigo à expedição e são vistos como um entrave ao andamento dos trabalhos de demarcação. Em outras palavras: encarnam a imagem dos chamados "índios bravos" ${ }^{18}$ Como fica nítido nessa passagem, a participação de outros grupos indígenas era fundamental não apenas em atividades práticas (como na condição de remadores), mas também, e sobretudo, como fonte de conhecimento local sobre aquele território e suas populações, tendo em vista sua qualidade de intérpretes. ${ }^{19}$ Assim, como contraponto aos "índios bravos" do vale do Javari, aparecem esses grupos de "índios mansos" como colaboradores e participantes da expedição.

Portanto, percebemos que existe uma trama bastante mais complexa de relações que permeiam a exploração desse território e que levaram à confecção deste mapa. Essas relações foram caladas na apresentação final do mapa. Os silêncios dos mapas são tão importantes quanto os aspectos retratados e enfatizados por seus autores (Harley, 2001: 67). Por isso mesmo, a informação da participação e atuação sistemática de povos indígenas na Comissão Mista de Limites de 1874 se torna não apenas importante como essencial. Esse dado revela o quanto a narrativa apresentada pela Carta do Alto Rio Javary insiste em uma imagem unívoca dessas populações nativas: o outro, o inimigo, a ameaça (e, em contrapartida, o heroísmo daqueles que se aventuraram por essas regiões). A figura do índio cumpre assim um papel único nesse quadro, enquanto, na realidade, as colaborações dessas populações indígenas locais são imprescindíveis para o mapeamento daquele território e daquela população. Fato corroborado pelo próprio barão de Tefé que, diante da falta de reconhecimento dos Ticunas e dos Jeveros sobre aquela população, afirma que era esta, então, população totalmente desconhecida. Ora, isso implica reconhecer que as informações sobre a população local vinham diretamente de outras populações indígenas. Em outras palavras: o conhecimento sobre aquela região dependia das populações locais.

Há algumas décadas a historiografia da ciência vem examinando com maior cuidado o processo de produção do conhecimento científico, dando especial atenção às relaçães locais e globais nele existentes (Secord, 2004; Raj, 2013). Questionar a maneira pela qual o conhecimento é produzido convida à reflexão sobre o papel dos agentes envolvidos 
em tal processo. Assim, fica cada vez mais evidente o quanto a ciência é resultado de diversas contribuições. Por muito tempo, as contribuições de agentes locais foram negligenciadas. Atualmente, vemos o movimento contrário, na tentativa de resgatar e evidenciar a pluralidade desses conhecimentos e os sujeitos sociais a eles associados.

Buscamos aqui evidenciar justamente este aspecto, na medida em que os relatos da Comissão Mista de 1874 deixam claro a importância do conhecimento local e a necessidade demonstrada pelos comissários de demandar tais conhecimentos. É essencial que isto seja evidenciado tendo em vista o silenciamento ocorrido durante muitos anos sobre aquelas contribuições.

\section{Um marco no desconhecido}

41 Como qualquer imagem ou representação, o mapa nasce com uma dimensão dupla, ou seja, permite substituir algo (presença) que não está lá ao mesmo tempo que, ao fazê-lo, marca a sua debilidade ou mesmo falsidade, por não ser a coisa em si mas a representação desta coisa (ausência) (Gombrich, 1999; Belting, 2005; Marin, 2009). A carta de que tratamos neste artigo contém essa dimensão dupla. Este documento, buscando afirmar o domínio do Estado sobre certo território - já que pela primeira vez uma comissão conseguiu chegar às nascentes do rio Javari -, mostra justamente o contrário, visto que os comentários existentes no mapa evidenciam o domínio do território em questão pelas populações autóctones, freado unicamente pelo uso das armas de fogo dos membros da comissão de 1874. A própria imagem do mapa é reveladora neste sentido já que ela se constitui de dois enormes espaços "vazios", separados unicamente por uma linha tortuosa que se estende do canto superior direito ao canto inferior esquerdo. Esta linha, o curso do rio Javari, era o único caminho possível para o trânsito dos agentes do Estado no imenso espaço vazio destacado no mapa, ocupado por populações nativas.

42 Analisando a geografia do desconhecido, Carla Lois nos convida a refletir sobre o significado desses espaços em branco mostrados nos mapas, algumas vezes identificados como terras incógnitas:

O desconhecido é mais uma forma de expressar certa insatisfação a respeito do conhecimento disponível e, ao mesmo tempo, demonstra a impossibilidade de produzir esse conhecimento, a inacessibilidade a esse objeto geográfico em termos epistemologicamente aceitáveis. Nesse sentido, o desconhecido é um modo de anunciar a inacessibilidade a um lugar ou a uma coisa... (Lois, 2018: 13) ${ }^{20}$

Assim, os espaços vazios existentes na CARJ podem ser indicativos dessa impossibilidade de produzir conhecimento sobre esses territórios, já que eles são de difícil acesso devido às densas florestas. No entanto, há outra dimensão da condição do desconhecido: "o desconhecido é algo estrangeiro (...) sua inacessibilidade remete à dificuldade quase intransponível de produzir conhecimento sobre elas [terrae incognitae] e de criar representações que permitam pensá-las e visualizá-las" (Lois, 2018: 15). ${ }^{21}$ Aqui aparece uma nova perspectiva: em que medida podemos perceber nesses grandes espaços vazios da CARJ a ausência (por impossibilidade ou desinteresse) de uma outra forma de reconhecimento desse espaço?

Façamos agora o exercício de olhar o mapa como se fosse um negativo fotográfico e tentemos perceber os espaços de outra maneira. Ao se "preencher" os espaços vazios: o que encontramos neles? Árvores, plantas, flores, folhas, animais; em resumo, uma 
grande floresta com sua fauna e flora. Considerando que o mapa mostra o alto curso desse rio, ou seja, a parte mais próxima das nascentes, podemos imaginar que essa vegetação deslumbrante se aproxima cada vez mais em cada uma de suas margens e que, em algum ponto, as copas das árvores já se projetam umas sobre as outras ou estão tão próximas que se torna possível a passagem de pequenos animais de um lado para o outro. Além disso, não podemos esquecer do elemento humano presente no ambiente: as populações indígenas. Estas circulam igualmente de um lado para o outro através da construção de pontes feitas com troncos de árvores. Essas pontes representavam um grande obstáculo para as comissões que precisavam passar algumas horas cortando as enormes árvores para seguir viagem. No entanto, sua presença indica um elemento essencial: aquele era um espaço de circulação e de fluidez, mas não no único sentido considerados pelos exploradores: o curso do rio, de montante a jusante. Tanto as populações indígenas quanto os animais ocupavam ambas margens do Javari. De maneira que o rio era uma passagem, e não um limite.

No entanto, a representação do território não deixa dúvidas: a área, embora "desconhecida", torna-se objeto de apropriação estatal por meio de duas comissões cartográficas nacionais: o Império do Brasil e a República do Peru afirmam a posse deste território através do mapa. Não existe, assim, a possibilidade de representar esse espaço de outra maneira, ou melhor: a CARJ existe justamente para garantir sua apropriação. Nesse sentido, outro elemento deve ser destacado. Na parte inferior direita do mapa aparece a indicação de um marco cujas coordenadas são assinaladas (figura 6). A partir dele uma linha pontilhada indica o caminho até as vertentes do rio, essas últimas assinaladas por linhas igualmente pontilhadas. O marco ganha destaque já que as vertentes do rio, apesar de serem assinaladas, não possuem coordenadas. ${ }^{22}$ 
Figura 9 - Carta do Alto Rio Javary, Bibiano da Fontoura Costallat, 1876.

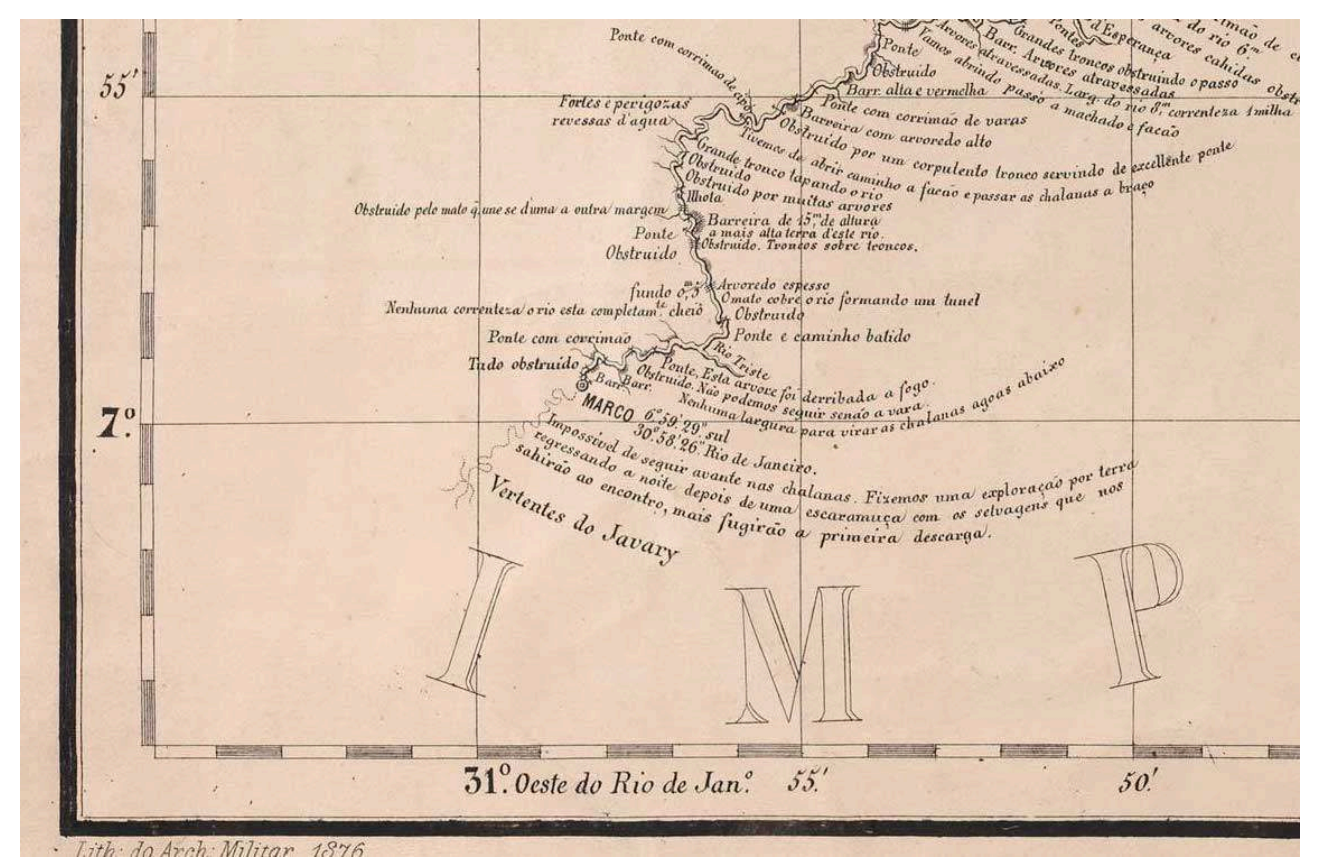

Notar a diferença entre a representação do rio Javari até o marco e a indicação do caminho depois dele através de linhas pontilhadas, na direção das vertentes do rio. Essas são indicadas com pouca precisão e contrastam com o marco, esse possui as coordenadas indicadas no mapa, ao contrário das vertentes.

Fonte: Biblioteca Nacional Digital. Biblioteca Nacional do Brasil. http://objdigital.bn.br/objdigital2/ acervo_digital/div_cartografia/cart176173/cart176173.jpg

O marco foi feito de "madeira chamada piquiá e em forma de cruz, como símbolo de redenção para as desgraçadas tribos de selvagens que povoam estas regiões, sendo sua altura de 20 pés. Acha-se colocado em terra firme e em posição que não chega a água" (Brasil. Relatório..., 1875: 190). Colocar o marco naqueles confins era dar materialidade à conquista do território. Este ato era tão ou mais importante que chegar às nascentes do Javari. Por isso o marco ganha destaque no mapa. Ali, naquele ponto, naquelas coordenadas, esteve a comissão demarcadora e deixou uma marca, lançou uma âncora num mar de incerteza, a partir da qual estaria garantida a posse daquelas terras. ${ }^{23} \mathrm{O}$ marco simbolizava a presença ausente dos Estados sul-americanos no vale do Javari. A comissão de 1874 trazia o duplo daquele território em forma de mapa e deixava um duplo naquele espaço, em forma de cruz.

\section{BIBLIOGRAFIA}

Arisi, Barbara e Milanez, Felipe (2017). Isolados e ilhados: indigenismo e conflitos no Vale do Javari, Amazônia. Estudos Ibero-Americanos, Porto Alegre, v. 43, n.1, pp. 49-66.

Belting, Hans (2005). "Por uma antropologia da imagem". Concinnitas, Rio de Janeiro: UERJ, ano 6, v. 1, n. 8 . 
Capilé, Bruno; Vergara, Moema (2012). “Circunstâncias da Cartografia no Brasil oitocentista e a necessidade de uma Carta Geral do Império". Revista Brasileira de História da Ciência, Rio de Janeiro, v. 5, n. 1, p. 37-49.

Corrêa, Roberto Lobato (1987). “A periodização da rede urbana na Amazônia”. Revista Brasileira de Geografia, ano 49, n. 3. Rio de Janeiro: IBGE, pp. 39-68.

Coutinho, Walter (2017). Gente Valente: uma Coletânea Matsés. Histórias Indígenas no Vale do Javari (1866-1974). Tese de Doutorado, Programa de Pós-Graduação em Antropologia Social, Universidade de Brasília, Brasília.

Cunha, Manuela Carneiro da (1998). "Política indigenista no século XIX”. In: Cunha, Manuela Cordeiro da (Org.). História dos Índios no Brasil. São Paulo: Fapesp/Cia das Letras, 2. ed.

Gombrich, Ernst. H. (1999). Meditações sobre um cavalinho de pau e outros ensaios sobre a teoria da arte. São Paulo: Editora da Universidade de São Paulo.

Harley, John B. (2001). “Maps, Knowledge and Power”. In: Harley, John B. The New Nature of Maps: essays in historical cartography. Baltimore: Johns Hopkins University Press.

Kodama, Kaori (2009). Os Índios no Império do Brasil: a etnografia do IHGB entre as décadas de 1840 e 1860. Rio de Janeiro: Editora FIOCRUZ; São Paulo: EDUSP.

Lois, Carla (2018). Terrae Incognitae. Modos de pensar y mapear geografías desconocidas. Buenos Aires: EUDEBA.

Machado, Lia Osorio (1996) O controle intermitente do território amazônico. Revista Território, LAGET-UFRJ, v. 1, n. 2 (Jan./Jun. 1997), Rio de Janeiro: Relume-Dumará.

Magnoli, Demétrio (1997). o Corpo da Pátria. São Paulo: Moderna/UNESP.

Marin, Louis (2009). “Poder, representación, imagen”. Prismas, Revista de historia intelectual, n. 13, pp. 135-153.

Mattos, Ilmar Rohloff de (2004). o Tempo Saquarema. São Paulo: Hucitec.

Moraes, Antonio Carlos Robert (2002). Território e História no Brasil, São Paulo: Annablume, 3ae ed.

Nascimento, Hilton S. do (2011). “Los pueblos indígenas aislados de la frontera Brasil-Perú: nuevas amenazas y desafíos para la garantía de sus derechos”. Mundo Amazônico, volume 2, pp. 179-198.

Peixoto, Renato Amado (2002). “O mapa antes do território. O Rio Javari e a Construção do Espaço Nacional”. Trajetos, v. 2, n. 3, p. 139-151.

Raj, Kapil (2013). Beyond Postcolonialism... and Postpositivism: Circulation and the Global History of Science, Isis, v. 104, n. 2, pp. 337-347.

Secord, James (2004). Knowledge in transit. Isis, v. 95, pp. 654-672.

Tefé, Barão de (1888). "Episódios da viagem de exploração às vertentes do famoso rio Javari, afluente meridional do Alto Amazonas". Revista da Sociedade de Geographia do Rio de Janeiro, tomo IV, 3o Boletim, Rio de Janeiro: Typographia Perseverança, pp. 169-188.

Vergara, Moema (2010). “Ciências, fronteiras e nação: comissões brasileiras na demarcação dos limites territoriais entre Brasil e Bolívia 1895-1901”. Boletim do Museu Paraense Emilio Goeldi. Ciências Humanas, Belém, v. 5, n. 2, pp. 345-361.

Xavier, Cesar Feliciano (1938). “Elogio geográfico-histórico do Almirante Barão de Tefé”. Revista da Sociedade de Geografia do Rio de Janeiro, tomo XLV, pp. 73-104. 


\section{ANEXOS}

\section{Arquivos}

ANB - Arquivo Nacional do Brasil, Rio de Janeiro

BNB - Biblioteca Nacional do Brasil, Rio de Janeiro

Fontes

1. Mapas

Carta do rio Içá. Levantada pelo capitão-tenente José da Costa Azevedo. Rio de Janeiro: Lith. Arch. Militar, 1868. Biblioteca Nacional Digital. Biblioteca Nacional do Brasil.

<http://objdigital.bn.br/objdigital2/acervo_digital/div_cartografia/cart1030061/ cart1030061.jpg>. Acesso em: 17 de junho de 2019.

Carta do Alto Rio Javary. Reduzida pelo bacharel Bibiano S. Macedo da Fontoura Costallat. Litografia do Arch. Militar, 1876. Biblioteca Nacional Digital. Biblioteca Nacional do Brasil.

<http://objdigital.bn.br/objdigital2/acervo_digital/div_cartografia/cart176173/ cart176173.jpg>. Acesso em: 17 de junho de 2018.

Carta do Rio Javary. Levantada e construída sob a direção do Comissário José da Costa Azevedo pelos Srs. Capitão-tenente João Soares Pinto, $1^{\mathfrak{o}}$ Tenente da Armada Geraldo Candido Martins e $1^{\circ}$ Tenente de Engenheiros José Antônio Rodrigues, Rio de Janeiro: Lith. Arch. Militar. 1868. Sistema de Informações do Arquivo Nacional. Arquivo Nacional do Brasil. <http://sian.an.gov.br/sianex/Consulta/

Pesquisa_Livre_Painel_Resultado.asp?v_CodReferencia_id=93748\&v_aba=1>. Acesso em: 17 de junho de 2019.

Carta Hydrographica do Rio Javary. Levantada por ordem do capitão-tenente José da Costa Azevedo, Comissário de limites do Brasil, para servir à Comissão mista, do Império e da República do Peru, no deslindar a fronteira nesta parte, segundo o Tratado de 23 de outubro de 1851, desenho a nanquim [João Soares Pinto], 1866. Sistema de Informações do Arquivo Nacional. Arquivo Nacional do Brasil.

<http://sian.an.gov.br/sianex/Consulta/Pesquisa_Livre_Painel_Resultado.asp? v_CodReferencia_id=95656\&v_aba=1>. Acesso em: 17 de junho de 2019.

Esboço Geográfico organizado em conformidade de documentos oficiais e outros valiosos, com o fim principal de mostrar a fronteira do Brasil no território compreendido entre os rios Madeira e Javari. Org. por Duarte da Ponte Ribeiro. Rio de Janeiro: Lith. Arch. Militar, 1874. Sistema de Informações do Arquivo Nacional, Arquivo Nacional do Brasil.

$<$ http://sian.an.gov.br/sianex/Consulta/Pesquisa_Livre_Painel_Resultado.asp? v_CodReferencia_id=340393\&v_aba=1>. Acesso em: 23 de agosto de 2019.

2. Documentos

2.1. Ofícios

Ofício no 80 do $1^{\circ}$ tenente José Antônio Rodrigues ao $1^{\circ}$ tenente Geraldo Candido Martins. Rio Javary, 16 de outubro de 1866. 
Ofício $\mathrm{n}^{\circ} 81$ do $1^{\circ}$ tenente Geraldo Martins ao capitão-tenente José da Costa Azevedo, Bordo da canhoneira Ibicuhy , 26 de outubro de 1866.

\subsection{Tratados}

Brasil. Convenção Especial de Comércio, Navegação Fluvial, Extradição e Limites BrasilPeru, 23 de outubro de 1851. Disponível em: <https://sistemas.mre.gov.br/kitweb/ datafiles/Pcdl/pt-br/file/Fronteiras/Peru/ C\%C3\%B3pia\%20dos\%20Tratados\%20de\%20Limites.pdf>. Acesso em: 10 de dezembro de 2018.

Brasil. O Tratado de limites Brasil-Peru. Brasília: Senado Federal, Conselho Editorial, 2009.

\subsection{Relatórios}

Brasil. Relatório da Repartição dos Negócios Estrangeiros, Rio de Janeiro: Typographia Universal de Laemmert, 1867.

$<$ http://ddsnext.crl.edu/titles/105\#?

$\mathrm{c}=0 \& \mathrm{~m}=38 \& \mathrm{~s}=0 \& \mathrm{cv}=0 \& \mathrm{r}=0 \& \mathrm{xywh}=-267 \% 2 \mathrm{C}-544 \% 2 \mathrm{C} 4337 \% 2 \mathrm{C} 3060>$. Acesso em: $10 \mathrm{de}$ junho de 2019.

Brasil. Relatório da Repartição dos Negócios Estrangeiros, Rio de Janeiro: Typographia Universal de Laemmert, 1871. <http://ddsnext.crl.edu/titles/105\#? $\mathrm{c}=0 \& \mathrm{~m}=42 \& \mathrm{~s}=0 \& \mathrm{cv}=0 \& \mathrm{r}=0 \& \mathrm{xywh}=-295 \% 2 \mathrm{C} 0 \% 2 \mathrm{C} 3708 \% 2 \mathrm{C} 2616>$. Acesso em: 10 de junho de 2019.

Brasil. Relatório da Repartição dos Negócios Estrangeiros, Rio de Janeiro: Typographia Universal de Laemmert, 1873. <http://ddsnext.crl.edu/titles/105\#? $\mathrm{c}=0 \& \mathrm{~m}=45 \& \mathrm{~s}=0 \& \mathrm{cv}=0 \& \mathrm{r}=0 \& \mathrm{xywh}=-259 \% 2 \mathrm{C}-538 \% 2 \mathrm{C} 4319 \% 2 \mathrm{C} 3047>$. Acesso em: $10 \mathrm{de}$ junho de 2019.

Brasil. Relatório da Repartição dos Negócios Estrangeiros, Rio de Janeiro: Typographia Universal de Laemmert, 1875.

$<\mathrm{http}: / /$ ddsnext.crl.edu/titles/105\#? $c=0 \& m=47 \& s=0 \& c v=218 \& r=0 \& x y w h=-301 \% 2 C-336 \% 2 C 2621 \% 2 C 1848>$. Acesso em: $20 \mathrm{de}$ junho de 2019.

\subsection{Outros}

Brasil. Ministério das Relações Exteriores. $1^{\text {a }}$ Comissão Brasileira Demarcadora de Limites. Resumo histórico. S/p. Disponível em: <https://sistemas.mre.gov.br/kitweb/ datafiles/Pcdl/pt-br/file/Fronteiras/Peru/Resumo\%20Hist\%C3\%B3rico.pdf>. Acesso em: 10 de dezembro de 2018.

\section{NOTAS}

1. Nesse sentido, vale lembrar sua participação na observação da passagem de Vênus de 1882 , entre outras atividades que fizeram com que fosse lembrado como homem de guerra e cientista. Para estas informações, ver a biografia detalhada e laudatória escrita por Cesar Feliciano Xavier (1938). 
2. Não nos foi possível localizar o mapa original durante a elaboração deste artigo. Contudo, há informações de que ele recebeu uma medalha de ouro na Exposição Universal de Paris de 1889, assim como uma medalha da Sociedade de Geografia do Rio de Janeiro (Xavier, 1938).

3. Sobre as diversas comissões que buscaram estabelecer a fronteira entre Brasil e Bolívia no século XIX e início do XX, ver Vergara (2010).

4. Segundo a autora, o atual Sudeste e a produção de café que ocupavam posição de destaque na política imperial.

5. Cabe lembrar aqui da relação entre a afirmação do Estado brasileiro no século XIX e a demarcação de fronteiras no território nacional, entendido como o corpo da nação, aquilo que lhe dá não só forma, como, no caso brasileiro, identidade. Este tema crucial possui ampla bibliografia, dentre a qual destacamos Mattos (2004), Moraes (2002) e Magnoli (1997).

6. Para facilitar a leitura e compreensão das fontes, a ortografia dos textos foi atualizada sempre que isto se fez necessário, com exceção das cartas examinadas.

7. Um resumo histórico dessas comissões de limites pode ser encontrado no site do Itamaraty, disponível em: <http://pcdl.itamaraty.gov.br//pt-br/brasil-peru.xmlı. Acesso em: 03 de novembro de 2018. Para um comentário sobre os Tratados e as reivindicações presentes na fronteira Brasil-Peru ver Brasil. O Tratado de Limites Brasil-Peru, 2009.

8. Na folha 2 também aparece a indicação: "lugar da antiga aldeia dos Mangeronas".

9. Ofício $n^{\circ} 80$ do $1^{\circ}$ tenente José Antônio Rodrigues ao $1^{\circ}$ tenente Geraldo Candido Martins. Rio Javary, 16 de outubro de 1866 (BRASIL. Relatório..., 1867).

10. Ofício $\mathrm{n}^{\circ} 81$ do $1^{\circ}$ tenente Geraldo Martins ao capitão-tenente José da Costa Azevedo, Bordo da canhoneira Ibicuhy , 26 de outubro de 1866 (Brasil. Relatório..., 1867).

11. Essa informação também aparece na Carta Hydrographica do Rio Javary (1866), como vimos.

12. “A legitimação da demarcação física do Império ia sendo respaldada por formas diferentes de trabalhos geográficos que colaboravam no acréscimo do conhecimento ao território. Corografias, mapas, itinerários, memórias sobre limites e mesmo as polêmicas indicam a importância atribuída ao conhecimento do território, conhecimento que, como já visto, acabava por incluir em seu conteúdo as nações indígenas associadas ao espaço que ocupavam nos sertões ignotos" (Kodama, 2009: 40).

13. "Na categoria de índios bravos, passam a ser incorporados os grupos que vão sendo progressivamente encontrados e guerreados nas fronteiras do Império: grupos dos afluentes do rio Amazonas, do Araguaia que se quer agora abrir à navegação, do Madeira, do Purus, do Jauaperi, e de outros tantos rios" (Cunha, 1998: 136). Como vemos, o rio Javari encontra-se precisamente neste conjunto mais amplo de territórios explorados a partir dos rios amazônicos cujas populações nativas foram vistas como inimigas.

14. Indicações como: "pontes", "um formidável tronco de pau mulato tapando o rio como ponte", "ponte com corrimão de cipó. Arvore tapando o rio" são numerosas a partir deste trecho até as nascentes do rio indicadas na CARJ.

15. Considerando somente as mortes provocadas por estes confrontos violentos, já que diversos membros dessa comissão morreram devido a outras causas, sendo a principal delas a doença do beribéri. Dos 82 membros que compunham a comissão no início da viagem, segundo o Barão de Tefé, apenas 55 alcançaram as nascentes do rio Javari (Tefé, 1888: 173)

16. Na parte peruana da fronteira o etnônimo Matsés é mais comum. Coutinho afirma que esse etnônimo "foi adotado desde o final daquela década [1970] pelas agências de governo do Peru, aparecendo inclusive na concessão do título de sua Comunidad Nativa e da contígua Reserva Territorial, os Matsés que habitam o território do país vizinho [Peru] também assumiram abertamente essa denominação e passaram a ser tratados dessa forma nas relações interétnicas estabelecidas com a sociedade nacional peruana" (Coutinho, 2017: p. 24-25).

17. Sobre a relação entre os Matsés e os Mayoruna, Coutinho afirma: “(a) o rótulo Mayoruna foi utilizado historicamente para um conjunto de grupos que não compunham necessariamente um 
único povo ou sociedade indígena e, portanto, (b) é incorreto postular que os Matsés sejam descendentes de todos os grupos assim denominados no correr da história, embora se possa supor que estejam relacionados intrinsecamente a alguns deles. Com efeito, o que dota de certa unidade a categoria Mayoruna ao longo dos períodos aqui sucessivamente considerados são, antes, certas representações e práticas dos agentes das sociedades nacionais envolventes que vieram a se relacionar, de algum modo, com os grupos indígenas assim chamados. Considerados 'selvagens', esses índios contrapuseram-se longamente à ocupação não indígena na bacia do Javari” (Coutinho, 2017: 46).

18. Ver nota 14.

19. Poderíamos incluir também nessa última categoria a própria condição de remadores atribuída aos Ticunas já que essa condição poderia estar menos atrelada à necessidade de braços para remar e mais atrelada aos conhecimentos indígenas de navegabilidade dos rios amazônicos. Dessa forma, a condição de remadores também pode ser entendida como uma manifestação do apelo feito ao conhecimento local da paisagem, dos rios e da melhor maneira de navegá-los.

20. No original: “Lo desconocido es, más bien, uma forma de expresar cierta insatisfacción respecto del conocimiento disponible $y$, al mismo tiempo, declama la impossibilidad de producir ese conocimiento, la inaccesibilidad a esse objeto geográfico em términos epistemológicamente aceptables. En esse sentido, lo desconocido es um modo de enunciar la inaccesibilidad a um lugar o a uma cosa". Tradução nossa.

21. No original: "lo desconocido es algo extranjero (...) su inaccesibilidad remite a la dificultad casi insalvable de producir conocimiento sobre ellas y de crear representaciones que permitan pensarlas y visualizarlas". Tradução nossa.

22. As coordenadas das vertentes não foram calculadas no momento da expedição e sim posteriormente, quando os membros da comissão estavam em Tabatinga (Brasil. Relatório..., 1875: 190). Cabe dizer que a latitude da vertente principal do rio está sinalizada no título do mapa, mas não nas linhas pontilhadas que mostram o itinerário da expedição. $\mathrm{O}$ cálculo das vertentes não foi feito no momento da expedição e sim posteriormente, quando os membros da comissão estavam em Tabatinga (Id., ibid.). Este fato pode explicar a ausência das coordenadas completas no mapa.

23. Nesse sentido, é interessante citar que o marco deixado nas margens do Javari vai ser rapidamente incorporado à produção cartografia imperial para demonstrar a demarcação daquelas áreas de fronteira. Um mapa do barão Duarte da Ponte Ribeiro (Esboço Geographico..., 1874) já mostrava a indicação do marco próximo às nascentes do Javari como uma maneira de demonstrar o controle sobre aquela área de fronteira.

\section{RESUMOS}

Durante o Império brasileiro houve um esforço para o estabelecimento e demarcação das fronteiras nacionais. Uma parte da fronteira Noroeste (entre o Brasil e o Peru) era delimitada por um rio: o rio Javari. A partir de 1851, duas comissões brasileiro-peruanas buscaram estabelecer e demarcar o leito desse rio. o objetivo principal desse artigo é propor uma análise do mapa produzido a partir dos trabalhos da Comissão Mista de Limites entre o Brasil e o Peru de 1874: a "Carta do Alto Rio Javary". A partir desse documento buscamos debater a maneira de representar esse espaço, a narrativa que é construída sobre as populações indígenas do vale do Javari, assim 
como refletir sobre os processos de produção do conhecimento a partir dos agentes envolvidos nesse processo.

Throughout the imperial period in Brazil, efforts were made to establish and demarcate national borders. The North-West frontier between Brazil and Peru was partially delimited by a river: the Javari river. From 1851 on, two Brazilian-Peruvian commissions tried to establish and demarcate that river's stream bed. This article's main purpose is to analyse the map produced from works carried out by the Brazil-Peru Mixed Commission of Borders in 1874: the Chart of High Javary River (Carta do Alto Rio Javary). Based on this document, we debate how this space was represented and the narrative which is constructed on indigenous populations that dwelled in the Javari river valley. Moreover, the article reflects upon the processes of construction of knowledge by focusing on agents that were involved in this process.

Durante el Imperio brasilero hubo un esfuerzo para el establecimiento y demarcación de las fronteras nacionales. Una parte de la frontera noroeste (entre Brasil y Perú) era delimitada por el río Javarí. A partir de 1851, dos comisiones brasilero-peruanas buscaron establecer y demarcar el lecho de ese río. El objetivo principal de este artículo es proponer un análisis del mapa producido a partir de los trabajos de la Comisión Mixta de Límites entre Brasil y Perú de 1874: la "Carta do Alto Rio Javary". A partir de este documento buscamos debatir sobre la manera de representar este espacio, la narrativa que es construída sobre las poblaciones indígenas del valle del Javarí, así como reflexionar sobre los procesos de producción de conocimiento a partir de los agentes incolugrados en este proceso.

Pendant l'Empire du Brésil, des efforts ont été faits afin d'établir et de délimiter les frontières nationales. La frontière au nord-ouest, entre le Brésil et le Pérou, a été partiellement delimitée en utilisant une rivière comme référence: la rivière Javary. Dès 1851, deux comissions brésiliennespéruviennes ont essayé d'établir et délimiter le lit de cette rivière. Le but de cet article est de proposer une analyse de la carte produite suite aux travaux de la comission mixte des limites entre le Brésil et le Pérou: la carte de la rivière Javari. En prenant ce document comme source, nous montrons comment cet espace a été representé, la narrative qui a été construite par rapport aux populations indigènes autour de la rivière Javari, ainsi que les processus de construction de la connaissance en mettant en évidence les agents de ces processus.

\section{ÍNDICE}

Índice geográfico: Amazônia, Fronteira Brasil-Peru, rio Javari

Mots-clés: Empire du Brésil, frontier Brésil-Pérou, rivière Javari, populations indigènes, Baron de Tefé

Índice cronológico: 1851-1889

Palavras-chave: Império do Brasil, fronteira Brasil-Peru, rio Javari, populações indígenas, barão de Tefé

Keywords: Empire of Brazil, Brazil-Peru border, Javari river, indigenous populations, baron of Tefé

Palabras claves: Imperio de Brasil, frontera Brasil-Peru, río Javarí, poblaciones 
AUTOR

\section{SABINA ALEXANDRE LUZ}

Doutoranda do Programa de Pós-Graduação em História da Universidade Federal do Estado do Rio de Janeiro (UNIRIO). 